\title{
Remembering David Shephard, MB FRCPC (1930-2011)
}

\author{
Kim Turner, MD
}

Received: 20 January 2012/ Accepted: 17 February 2012/Published online: 13 March 2012

(c) Canadian Anesthesiologists' Society 2012

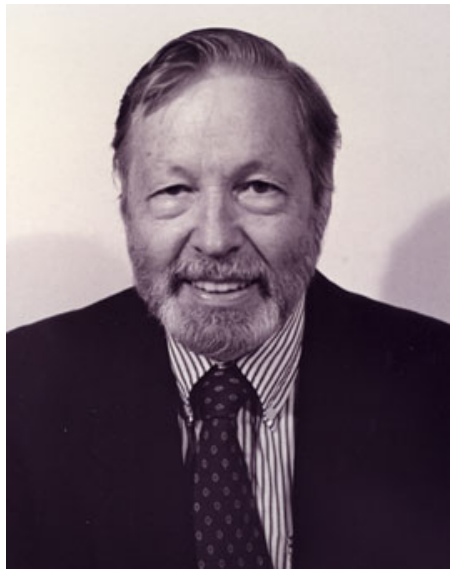

Dr. David Shephard, an eloquent and distinguished physician and talented medical writer, died on July 17, 2011 in Thunder Bay Ontario at the age of 81 . Without a doubt, Dr. Shephard will be fondly remembered by those with an interest in the history of our profession. He possessed unsurpassed knowledge and dedication to the history of anesthesia, particularly past accomplishments in Canadian Anesthesia.

David Arthur Easton Shephard was born on April 4, 1930 in Southsea England. He completed his secondary school education at Marlborough College, Wiltshire, England and studied medicine at the historic St. Thomas's Hospital Medical School and London University in the United Kingdom. Dr. Shephard then pursued a career in

K. Turner, MD ( $\square)$

Departments of Anesthesiology \& Perioperative Medicine and Community Health \& Epidemiology, Queen's University, Kingston General Hospital, 76 Stuart Street, Kingston, ON K7L 2V7, Canada

e-mail: turnerk@kgh.kari.net anesthesia initially completing residency training at St. Peter's Hospital, Chertsey and St. Bartholomew's Hospital, Rochester, UK. He completed additional residency training in anesthesia in the United States at the esteemed Peter Bent Brigham Hospital in Boston. Dr. Shephard practiced his chosen medical specialty of anesthesia in a multitude of settings, including the Royal Navy and in three countries, the United Kingdom, the United States, and Canada.

Dr. Shephard was an accomplished medical writer before becoming a distinguished medical historian. He was appointed editor of Scientific Publications (Biomedical Communications) at the Mayo Clinic and served in that role from 1972 to 1974 . He then served as Editor-in-Chief of the important Canadian Medical Association Journal in 1976. He became a Fellow of the American Medical Writers Association and then went on to become its President in 1979.

Dr. Shephard's passion for medical history became his lifelong vocation. He documented the history of a number of medical societies, including The Royal College of Physicians and Surgeons of Canada 1960-1980: The Pursuit of Unity, and the history of the Canadian Anesthesiologists' Society (CAS) in Watching Closely Those Who Sleep: A History of the Canadian Anaesthetists' Society, 1943-1993 as part of the $50^{\text {th }}$ anniversary celebrations of the CAS in 1993.

Dr. Shephard was the recipient of two Fellowships from the American Society of Anesthesiologists' Wood Library Museum as well as the Canadian Medical Association's John B. Nielson Award, which recognized his contribution to the study of the history of medicine. While serving as Archivist for the CAS, Dr. Shephard wrote numerous articles for the Journal regarding the influence of individuals on the advancement of anesthesia practice. In so doing, he ensured that many lives and lifelong contributions to our specialty were documented, highlighted, and 
preserved. Dr. Shephard's monographs for the CAS, An Exhibit of Inhalers and Vaporizers (1847 - 1968) and Preserving the History of Canadian Anesthesiology - A Panorama of People, Ideas, Techniques and Events, were both written to accompany displays at annual meetings and are currently accessible on the CAS website. He wrote and contributed to a large number of other manuscripts related to the history of medicine. His published books include: John Snow, Anaesthetist to a Queen and Epidemiologist to a Nation: A Biography (1995), Island doctor: John Mackieson and Medicine in Nineteenth-Century Prince Edward Island (2003), and most recently, From Craft to Specialty: A Medical and Social History of Anesthesia and Its Changing Role in Health Care in which he comprehensively traced, documented, and referenced the evolution of anesthesia practice from a craft to a specialty and its role in health care in the context of a changing society.

Dr. Shephard was a generous mentor who was always willing to share his extensive knowledge and to encourage those who were interested in the history of medicine, particularly over a meal or glass of wine. He enjoyed reading biographies and history, listening to opera and classical music, and playing bridge.

Through his life's work, Dr. Shephard ensured that individual's important contributions toward the advancement of our profession would be appreciated and remembered by future generations of anesthesiologists. In 2005, when Dr. Shephard stepped down from his position as Archivist for the Society, he was formally recognized for his outstanding contribution to the preservation of CAS history for future generations to enjoy and appreciate.

It is fitting that his contributions will live on in his multitude of written works and in the archival collection and artifacts which he carefully preserved for the Canadian Anesthesiologists' Society.

\section{À la mémoire du Dr David Shephard, MB FRCPC (1930-2011)}

Le Dr David Shephard, médecin éloquent et distingué, auteur médical de talent, est décédé le 17 juillet 2011 à Thunder Bay (Ontario), à l'âge de 81 ans. Le souvenir du Dr Shephard restera sans doute gravé dans la mémoire de ceux qui s'intéressent à l'histoire de notre discipline. Il avait en effet une connaissance inégalée de l'histoire de l'anesthésie, un sujet qui le passionnait, en particulier les moments forts de l'anesthésie au Canada.

David Arthur Easton Shephard est né le 4 avril 1930 à Southsea, en Angleterre. Il a effectué ses études secondaires au Marlborough College, dans le Wiltshire avant d'étudier à la faculté de médecine du St Thomas' Hospital, une vieille institution, et à la London University, toujours au Royaume-Uni. Le Dr Shephard a ensuite poursuivi une carrière en anesthésie après avoir terminé sa formation de résident à l'hôpital St. Peter, à Chertsey et à l'hôpital St. Bartholomew, à Rochester (R.-U.). Il a complété sa formation à Boston, aux États-Unis, par un stage postgradué dans un hôpital de renom, le Peter Bent Brigham Hospital. Le Dr Shephard a exercé la spécialité qu'il avait choisie dans de multiples environnements, dont la Royal Navy et dans trois pays différents, le Royaume-Uni, les États-Unis et le Canada.

Le Dr Shephard a été un auteur médical de talent avant de devenir un historien réputé de la médecine. Il fut nommé rédacteur de Scientific Publications (Biomedical Communications) de la Mayo Clinic et a occupé ce poste de 1972 à 1974. Il devint en 1976 le Rédacteur en chef de l'important Journal de l'Association médicale canadienne. Il devint membre de l'American Medical Writers Association, puis son président en 1979.

La passion du Dr Shephard pour l'histoire de la médecine fut sa véritable vocation. Il a documenté l'histoire d'un certain nombre de sociétés médicales dont celle du Collège royal des médecins et chirurgiens du Canada dans Le Collège royal des médecins et chirurgiens du Canada 1960-1980: à la recherche de l'unité et a tenu les chroniques de la Société canadienne des anesthésiologistes (CAS) dans Watching Closely Those Who Sleep: A History of the Canadian Anaesthetists' Society, 1943-1993 (surveiller étroitement ceux qui dorment: l'histoire de la SCA) dans le cadre de la célébration du 50 ${ }^{\mathrm{e}}$ anniversaire de la société en 1993.

Le Dr Shephard a reçu deux prix du Wood Library Museum de la Société américaine des anesthésiologistes ainsi que le prix John B. Nielson de l'Association médicale canadienne en reconnaissance de sa contribution à l'étude de l'histoire de la médecine. Dans son rôle d'archiviste de la CAS, le Dr Shepard a écrit de nombreux articles pour le Journal à propos de l'influence de certaines personnes sur les progrès de la pratique de l'anesthésie. Ce faisant, il s'est assuré que les biographies et les contributions de toute une vie de nombreux collègues envers notre spécialité soient documentées, mises en valeur et reconnues. Les monographies du Dr Shepard pour la CAS (Une exposition des inhalateurs et vaporisateurs [1847-1968] et Préservation de l'histoire de l'anesthésiologie canadienne: panorama des hommes, des idées, des techniques et événements) ont été écrites pour figurer lors des expositions dans le cadre de congrès annuels; elles sont actuellement disponibles sur le site internet de la CAS. Il a écrit et contribué à un grand nombre d'autres manuscrits traitant de l'histoire de la médecine. Il a publié plusieurs livres et notamment: John Snow, Anaesthetist to a Queen and 
Epidemiologist to a Nation: A Biography (1995), Island doctor: John Mackieson and Medicine in Nineteenth-Century Prince Edward Island (2003), et plus récemment From Craft to Specialty: A Medical and Social History of Anesthesia and Its Changing Role in Health Care dans lequel il a retracé de façon approfondie, documenté et poursuivi l'évolution de l'exercice de l'anesthésiologie depuis les temps où il s'agissait d'un travail artisanal à celui de l'exercice d'une spécialité, ainsi que son rôle dans les soins de santé, dans un contexte de société en évolution.

Le Dr Shephard était un mentor généreux, toujours prêt à partager ses grandes connaissances et à encourager ceux qui s'intéressaient à l'histoire de la médecine, en particulier autour d'un bon repas ou d'un verre de vin. Il aimait intensément lire des biographies et des livres sur l'histoire, écouter des opéras et de la musique classique et, enfin, jouer au bridge.
Tout au long de sa carrière, le Dr Shepard a veillé à ce que les importantes contributions d'individus aux progrès de notre profession soient appréciées à leur juste valeur et à ce que leur mémoire soit perpétuée par les futures générations d'anesthésiologistes. Quand, en 2005, le Dr Shephard a démissionné de son poste d'archiviste de la Société, sa contribution exceptionnelle à la conservation de l'histoire de la CAS pour le bénéfice des générations à venir a été officiellement reconnue.

Il est normal que ses contributions continuent à vivre au travers de la multitude de ses écrits et dans la collection d'archives et d'objets qu'il a soigneusement préservés pour la Société canadienne des anesthésiologistes.

Competing interests None declared. 